\title{
Physical and Biochemical Characterization of the qac $A$ Gene Encoding Antiseptic and Disinfectant Resistance in Staphylococcus aureus
}

\author{
By JAN M. TENNENT,${ }^{1} \dagger$ BRUCE R. LYON, ${ }^{1} \ddagger$ MELVIN MIDGLEY, ${ }^{2}$ \\ I. GWYN JONES, ${ }^{2}$ AMARJIT S. PUREWAL ${ }^{2}$ AND RONALD A. SKURRAY ${ }^{1 *}$ \\ ${ }^{1}$ Department of Microbiology, Monash University, Clayton, Victoria 3168, Australia \\ ${ }^{2}$ Department of Biochemistry, University of Hull, Hull HU6 7RX, UK
}

(Received 22 August 1988; accepted 18 October 1988)

\begin{abstract}
We have previously cloned a $3.5 \mathrm{~kb}$ fragment from the Staphylococcus aureus multiresistance plasmid pSK1 which carries the qacA determinant responsible for linked resistance to acriflavine $\left(\mathrm{Ac}^{\mathrm{r}}\right)$, ethidium bromide $\left(\mathrm{Eb}^{\mathrm{r}}\right)$, quaternary ammonium compounds $\left(\mathrm{Qa}^{\mathrm{r}}\right)$, propamidine isethionate $\left(\mathrm{Pi}^{\mathrm{r}}\right)$, and diamidinodiphenylamine dihydrochloride $\left(\mathrm{Dd}^{\mathrm{r}}\right)$. This report presents a biochemical and physical analysis of $q a c A$ and shows the widespread carriage of this gene on $S$. aureus resistance plasmids. Tn 5 insertion mutagenesis defined the extent of $q a c A$ to within $2.40 \mathrm{~kb}$ of pSK1 DNA. Examination of the expression of insertion and deletion mutants of the cloned qacA sequences in both maxicells and minicells led to the association of a $50 \mathrm{kDa}$ protein, designated QacA, with the $\mathrm{Ac}^{r} \mathrm{~Eb}^{r} \mathrm{Qa}^{r} \mathrm{Pi}^{r} \mathrm{Dd}^{r}$ phenotype. Based on fluorimetric and isotopic assays used to determine the extent of accumulation of ethidium bromide by $S$. aureus strains harbouring pSK1, we propose that the basis of $\mathrm{Ac}^{r} \mathrm{~Eb}^{r} \mathrm{Qa}^{r} \mathrm{Pi}^{r} \mathrm{Dd}^{\mathrm{r}}$ in $S$. aureus is a qacAmediated efflux system.
\end{abstract}

\section{INTRODUCTION}

Previous genetic analyses have established that, in addition to resistance to the aminoglycosides gentamicin, tobramycin and kanamycin and to trimethoprim, the commonly detected Staphylococcus aureus plasmid pSK1 encodes resistance to acriflavine (Acr), ethidium bromide $\left(\mathrm{Eb}^{\mathrm{r}}\right)$, quaternary ammonium compounds $\left(\mathrm{Qa}^{\mathrm{r}}\right)$ such as cetrimide (cetyltrimethylammonium bromide) and benzalkonium chloride, and diamidines such as propamidine isethionate $(\mathrm{Pi})$ and diamidinodiphenylamine dihydrochloride $\left(\mathrm{Dd}^{\mathrm{r}}\right)$ (Lyon et al., 1984; Gillespie et al., 1986; Lyon \& Skurray, 1987). It has been suggested that the emergence of staphylococci resistant to these and related compounds may have been due to the frequent inclusion of such agents, particularly acriflavine and cetrimide, in antiseptics and disinfectants (Foster, 1983; Tennent $e t$ al., 1985). The genetic determinant carried by pSK 1 responsible for $\mathrm{Ac}^{r} \mathrm{~Eb}^{r} \mathrm{Qa}^{\mathrm{r}} \mathrm{Pi}^{\mathrm{r}} \mathrm{Dd}^{\mathrm{r}}$ has been designated qacA (Lyon \& Skurray, 1987). Restriction endonuclease analysis and DNA-DNA hybridization have established that $q a c A$ is also present on $\beta$-lactamase/heavy metal resistance plasmids detected in $S$. aureus strains collected during the early 1980s (Gillespie et al., 1986). Furthermore, we believe that $q a c A$ is equivalent to the determinants responsible for the type I nucleic acid binding resistance (Emslie et al., 1985, 1986) and for the antiseptic-resistant phenotypes of $S$. aureus isolates which have appeared in London (UK) hospitals in the last few years (Townsend et al., 1987; Cookson \& Phillips, 1988).

There exist up to four determinants besides qacA which mediate resistance to antiseptics and disinfectants in $S$. aureus. Of these, $q a c B$ shares restriction site identity and DNA sequence

$\dagger$ Present address: Department of Microbiology, University of Umeå, S-901 87, Umeå, Sweden.

$\ddagger$ Present address: CSIRO Division of Plant Industry, Canberra, ACT 2601, Australia. 
homology on the basis of hybridization experiments with qacA and is carried by $\beta$ lactamase/heavy metal resistance plasmids (Gillespie \& Skurray, 1986, and unpublished data; Lyon \& Skurray, 1987). However, we have distinguished between these two determinants on the basis of the levels of resistance they confer towards Ac, Eb, Qa, Pi and Dd. A third gene, designated $q a c C$, encodes $\mathrm{Qa}^{\mathrm{r}}$ and low-level $\mathrm{Eb}^{\mathrm{r}}$. qacC has been detected on a variety of 2-3 kb plasmids identified in $S$. aureus strains from Australia, Italy and North America (Emslie et al., 1986; Lyon \& Skurray, 1987; M. Gillespie \& R. Skurray, unpublished data). Phenotypically similar to $q a c C$, we have now defined the $q a c D$ and $q a c E$ antiseptic-resistance determinants as those genes carried by conjugative aminoglycoside-resistance plasmids isolated in North America (pSK41, pUW3626; Lyon et al., 1987a) and West Germany (pJE1; Evans \& Dyke, 1988), respectively. Although it is clear that $q a c C$, $q a c D$ and $q a c E$ are related on the basis of DNA hybridization studies, and are physically distinct from either of qacA or qacB (Lyon \& Skurray, 1987; M. Gillespie, J. Tennent, M. Midgley, G. Jones, A. Purewal \& R. Skurray, unpublished data), the exact relationship between the three former genes is yet to be fully examined.

The first investigation into the biochemistry of staphylococcal antiseptic and disinfectant resistance established that the mechanism of resistance attributable to qacE encoded by pJE1 involved an efflux system (Jones \& Midgley, 1985). In this study we have examined the physical and biochemical characteristics of qacA-mediated $\mathrm{Ac}^{r} \mathrm{~Eb}^{\mathrm{r}} \mathrm{Qa}^{r} \mathrm{Pi}^{\mathrm{r}} \mathrm{Dd}^{\mathrm{r}}$ in $S$. aureus.

\section{METHODS}

Bacterial strains and plasmids. Plasmid-free strains of S. aureus (SA113, SK982, SK983) used as recipients in DNA transfer experiments have been described previously (Lyon et al., 1984; Tennent et al., 1985). A description of the $S$. aureus strains and plasmids examined in this study is presented in Table 1 . Escherichia coli $\mathrm{K} 12$ derivatives used for the preparation of maxicells and minicells were CSR603 (Sancar et al., 1979) and ORN103 (Orndorff et al., 1985), respectively. Construction of the $S$. aureus $-E$. coli hybrid plasmid pSK 449 has been detailed elsewhere (Tennent et al., 1985).

General methods. Bacteria were routinely grown in L-broth or on L-agar containing appropriate antibiotics. All media and the method for the determination of antibiotic susceptibility have been previously described (Lyon et al., 1983; Tennent et al., 1985). Propamidine isethionate and diamidinodiphenylamine hydrochloride were generously donated by May \& Baker Australia Pty Ltd.

DNA manipulation procedures. The isolation of plasmid DNA, digestion with restriction endonucleases and agarose gel electrophoresis were performed as previously described (Lyon et al., 1983; Ray \& Skurray, 1983). Transposon mutagenesis with Tn 5 was done essentially according to Weaver et al. (1981) using phage $\lambda-467$ (Berg et al., 1975) as a source of the transposon. HindIII digests of $\lambda$ bacteriophage DNA were employed as standards; fragment sizes in kilobase pairs (kb) were as published (Daniels et al., 1983). DNA was transferred to nitrocellulose for hybridization analysis by the bidirectional procedure of Smith \& Summers (1980). A 0.85 kb HpaII DNA fragment which spans the qacA determinant was prepared from pSK 449 by electroelution, nicktranslated with $\left[\alpha^{-32} \mathrm{P}\right] \mathrm{dATP}\left(1800 \mathrm{Ci} \mathrm{mmol}^{-1}, 66.6 \mathrm{TBq} \mathrm{mmol}^{-1}\right)$ and hybridized in $50 \%(\mathrm{v} / \mathrm{v})$ formamide with

Table 1. S. aureus strains and plasmids

\begin{tabular}{|c|c|c|c|c|c|}
\hline \multirow[b]{2}{*}{ Strain } & \multirow[b]{2}{*}{ Background } & \multicolumn{3}{|c|}{ Plasmid } & \multirow[b]{2}{*}{ Reference } \\
\hline & & No. & Size $(k b)$ & Genotype* & \\
\hline SK982 & SA113 & - & & & Lyon et al. (1984) \\
\hline SK983 & SA113 & - & & & Tennent et al. (1985) \\
\hline SK2267 & SK982 & pSK 1 & 28.4 & aacA-aphD qacA dfrA & Skurray et al. (1988) \\
\hline SK257 & Clinical isolate & pSK9 & $25 \cdot 7$ & $a a c A-a p h D$ qacA & Skurray et al. (1988) \\
\hline SK 74 & Clinical isolate & pSK 14 & $24 \cdot 4$ & $a a c A-a p h D$ qacA & Skurray et al. (1988) \\
\hline SK 2408 & SA113 & pSK 16 & $35 \cdot 1$ & aacA-aphD qacA dfrA blaZ & Skurray et al. (1988) \\
\hline SK 2414 & SK982 & pSK 42 & $29 \cdot 75$ & $a a c A-a p h D$ qacA dfrA & This paper \\
\hline SK2392 & SK983 & pSK 78 & $25 \cdot 9$ & $a a c A-a p h D d f r A$ & Tennent et al. (1985) \\
\hline
\end{tabular}

* Other than $q a c A$, the genes shown encode resistance to: aacA-aphD, gentamicin, tobramycin and kanamycin; blaZ, penicillin; dfrA, trimethoprim. 
nitrocellulose filters carrying target DNA, using previously described techniques (Maniatis et al., 1982; Lyon et al., 1987a). Washed and dried filters were exposed to Fuji RX film at $-70^{\circ} \mathrm{C}$ for sufficient time to produce an acceptable autoradiograph.

Analysis of plasmid-encoded proteins. Maxicells were prepared from various CSR603 transformants and plasmidencoded proteins were labelled with $\left[{ }^{35}\right.$ S $]$ methionine according to the technique described by Sancar $e$ t al. (1979). Minicells were isolated from different ORN103 transformants and plasmid-encoded proteins were labelled with $\left[{ }^{35}\right.$ S]methionine as described by Thompson \& Achtman (1978). In both instances, radiolabelled polypeptide products were boiled for $3 \mathrm{~min}$ in sample buffer, separated by SDS-polyacrylamide gel electrophoresis (SDSPAGE) and detected by autoradiography or fluorography.

Measurement of ethidium efflux. The methods for the fluorimetric and isotopic assays employed in these determinations were based on previous studies (Jones \& Midgley, 1985; Midgley, 1986). The appropriate strain was grown for $16 \mathrm{~h}$ at $37^{\circ} \mathrm{C}$ in L-broth $(50 \mathrm{ml}$ ). This culture was used to inoculate $200 \mathrm{ml}$ of L-broth; after 90 $120 \mathrm{~min}$ at $37^{\circ} \mathrm{C}$, the cells were harvested, washed twice at $4^{\circ} \mathrm{C}$ in $20 \mathrm{mM}-\mathrm{HEPES} / \mathrm{NaOH}(\mathrm{pH} 7 \cdot 0$ ), and finally resuspended in the same buffer and kept on ice. Loading of the cells was by incubation for $35 \mathrm{~min}$ at $37^{\circ} \mathrm{C}$ at a cell density of $0.39 \mathrm{mg}$ dry wt ml ${ }^{-1}$ in the presence of $20 \mu \mathrm{M}$-carbonyl cyanide $m$-chlorophenylhydrazone and $5 \mu \mathrm{M}$ ethidium bromide. For radiochemical experiments, $\left[6-{ }^{14} \mathrm{C}\right]$ ethidium bromide was used at a specific activity of $3.3 \mu \mathrm{Ci} \mu \mathrm{mol}^{-1}\left(122 \mathrm{kBq} \mu \mathrm{mol}^{-1}\right)$. The cell suspension was then chilled and the cells were washed once more in the same buffer at $4{ }^{\circ} \mathrm{C}$. Formate- or glucose-driven efflux of ethidium was assayed as previously described (Midgley, 1986).

Measurement of respiration. Rates of respiration were measured using an oxygen electrode as described by Midgley (1986).

\section{RESULTS}

\section{Physical localization of the qacA determinant on pSK1}

We have previously demonstrated that a $3.5 \mathrm{~kb}$ segment of pSK1 DNA contains the qacA determinant and can express $\mathrm{Ac}^{r} \mathrm{~Eb}^{\mathrm{r}} \mathrm{Qa}^{\mathrm{r}}$ in $E$. coli when cloned into the plasmid vector pBR322 (Fig. 1; Tennent et al., 1985; Gillespie et al., 1986). This $S$. aureus-E. coli hybrid plasmid, pSK 449, has now been shown to confer on its $E$. coli host resistance to $\mathrm{Pi}\left(200 \mu \mathrm{g} \mathrm{ml}^{-1}\right)$ and $\mathrm{Dd}$ $\left(150 \mu \mathrm{g} \mathrm{ml}^{-1}\right)$ also. To localize the qacA region of pSK1 more precisely within the cloned staphylococcal DNA, pSK449 was mutagenized with the kanamycin/neomycin resistance transposon $\operatorname{Tn} 5$. From one experiment, 80 transformants containing pSK $449:: \operatorname{Tn} 5$ derivatives were obtained; 41 of these plasmids possessed Tn 5 insertions within the cloned pSK 1 segment. Of 24 insertion mutants subjected to restriction endonuclease analysis, 19 had $\operatorname{Tn} 5$ situated in pSK449 at distinguishable sites, with one mapping in the vector and the remaining 18 being located in the passenger DNA. The positions of the $19 \mathrm{Tn} 5$ insertions in pSK449 are depicted in Fig. 1.

Susceptibility testing revealed that 15 distinct insertions of Tn5 in pSK449 led to the concomitant loss of $\mathrm{Ac}^{r} \mathrm{~Eb}^{\mathrm{r}} \mathrm{Qa}^{\mathrm{r}} \mathrm{Pi}^{\mathrm{r}} \mathrm{Dd}^{\mathrm{r}}$. This result confirmed the notion that a single determinant, qac $A$, mediated resistance to all of these agents. The insertions mapped within a $1.45 \mathrm{~kb}$ region of pSK1 DNA (between coordinates 19.40 and 20.85 ) which encompassed two sites for each of HaeIII, HpaII and PvuII (Fig. 1). Three plasmids were identified which exhibited the full qacA phenotype of pSK449 and contained Tn5 insertions within the cloned staphylococcal fragment; one of these, pSK478, limited the leftward extent of the qacA determinant to 18.70 on the pSK1 map, whereas the locations of the other two (e.g. pSK 480) suggested that the cloned portion of IS256L (Lyon et al., 1987 b) played no role in mediating this phenotype. Plasmid pSK467 possessed a Tn5 insertion in pBR322 sequences which did not affect the expression of $q a c A$. On the basis of these data, the minimum and maximum extents of the qac $A$ determinant on pSK1 have been limited to $1.45 \mathrm{~kb}$ (coordinates 19.40-20.85) and $2 \cdot 40 \mathrm{~kb}$ (coordinates $18 \cdot 70-21 \cdot 10$ ), respectively.

\section{Demonstration of qacA sequences on $S$. aureus plasmids}

Plasmid pSK1 represents a family of structurally related plasmids detected in Australian isolates of multiresistant $S$. aureus. Of these plasmids, all but one encodes $\mathrm{Ac}^{r} \mathrm{~Eb}^{r} \mathrm{Qa}^{r} \mathrm{Pi}^{r} \mathrm{Dd}^{r}$ and most additionally mediate resistance to the aminoglycosides, trimethoprim and/or penicillin (Lyon \& Skurray, 1987; Skurray et al., 1988). Restriction endonuclease maps established for 


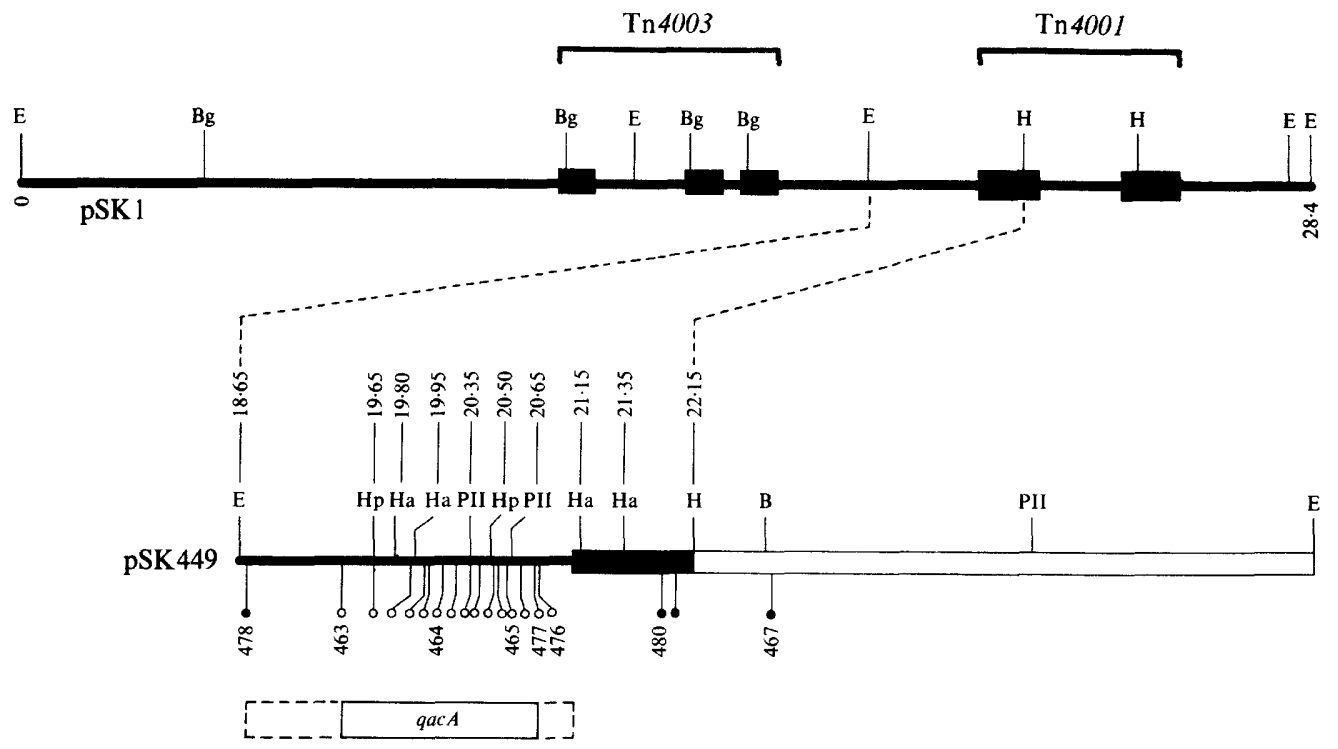

Fig. 1. Location of the qacA region of pSK1. Sites of Tn5 insertion into pSK449, with pSK numbers (e.g. pSK 478) given only for those plasmids used in the polypeptide analysis (Fig. $3 a$ ), are shown by circles joined to the pSK 449 linear map which has been aligned with a simplified physical map of pSK 1; filled (O) and open $(O)$ circles indicate $\mathrm{Ac}^{r} \mathrm{~Eb}^{r} \mathrm{Qa}^{r} \mathrm{Pi}^{r} \mathrm{Dd}^{r}$ and $\mathrm{Ac}^{\mathrm{s}} \mathrm{Eb}^{\mathrm{s}} \mathrm{Qa}^{\mathrm{s}} \mathrm{Pi}^{\mathrm{s}} \mathrm{Dd}^{\mathrm{s}}$ phenotypes, respectively. Thin lines represent pSK1 DNA sequences, whereas the IS256 inverted repeats of Tn 4001 and the IS 257 direct repeats of Tn4003 are shown as thick lines; pBR322 sequences of pSK449 are shown as thick (open) lines. Coordinates are in kb and refer to pSK 1 map coordinates; we have recalculated the size of the cloned fragment in pSK 449 to be $3.5 \mathrm{~kb}$ and not $3.4 \mathrm{~kb}$ as estimated previously by restriction endonuclease mapping (Tennent et al., 1985). Restriction endonuclease sites are given by B (BamHI), Bg (BgIII), E (EcoRI), H (HindIII), Ha (HaeIII), Hp (HpaII), and PII (PvuII). Only those HindIII sites of pSK 1 within Tn 4001 are indicated and only those HaeIII and HpaII sites of pSK 1 lying within the cloned fragment (expanded) are shown. A detailed map of pSK1 has appeared elsewhere (Lyon et al., 1987a). The dotted box in the lower part of the figure represents the maximum extent of the coding sequences of the qac $A$ determinant, whereas the solid box indicates the minimum extent of this region (see text).

these plasmids identified a DNA segment on each that shared restriction identity with the qacA region of pSK 1 (Skurray et al., 1988; our unpublished data). When digested with HpaII, five of the pSK 1 family plasmids (pSK1, pSK9, pSK14, pSK 16 and pSK42), together with pSK449, produced a $0.85 \mathrm{~kb}$ fragment (Fig. $2 a$, lanes B, C, D, E, F and H). In contrast, pSK 78, an in vitro deleted derivative of pSK1 which does not encode $\mathrm{Ac}^{\mathrm{r}} \mathrm{Eb}^{\mathrm{r}} \mathrm{Qa}^{\mathrm{r}} \mathrm{Pi}^{\mathrm{r}} \mathrm{Dd}^{\mathrm{r}}$ (Tennent et al., 1985), failed to produce a HpaII fragment of this size (Fig. $2 a$, lane G).

The transposon mutagenesis experiment described above also indicated that the $0.85 \mathrm{~kb}$ $H$ paII fragment of pSK1 was located entirely within the minimum extent of qacA (Fig. 1). Therefore, to confirm the presence of qacA sequences in each of the pSK 1 family plasmids, the $0.85 \mathrm{~kb} H p a I I$ fragment from pSK 449 was radiolabelled and hybridized with the HpaII-digested DNA in the gel shown in Fig. 2(a). As expected, the probe DNA hybridized with the $0.85 \mathrm{~kb}$ $H$ paII fragment from the plasmids pSK1, pSK9, pSK 14, pSK 16, pSK42 and pSK449 (Fig. $2 b$, lanes B, C, D, E, F and H) but not with any fragment of pSK78 (Fig. 2b, lane G). Subsequent analyses of six other pSK 1 family plasmids (pSK 4, pSK 7, pSK8, pSK15, pSK 17 and pSK 18) showed that each contained a similar-sized HpaII fragment which was homologous to the probe DNA used here (data not shown).

These hybridization results are in agreement with restriction mapping data (Skurray et al., 1988) and confirm the prevalence of the qacA determinant among members of the pSK 1 family of $S$. aureus resistance plasmids. 


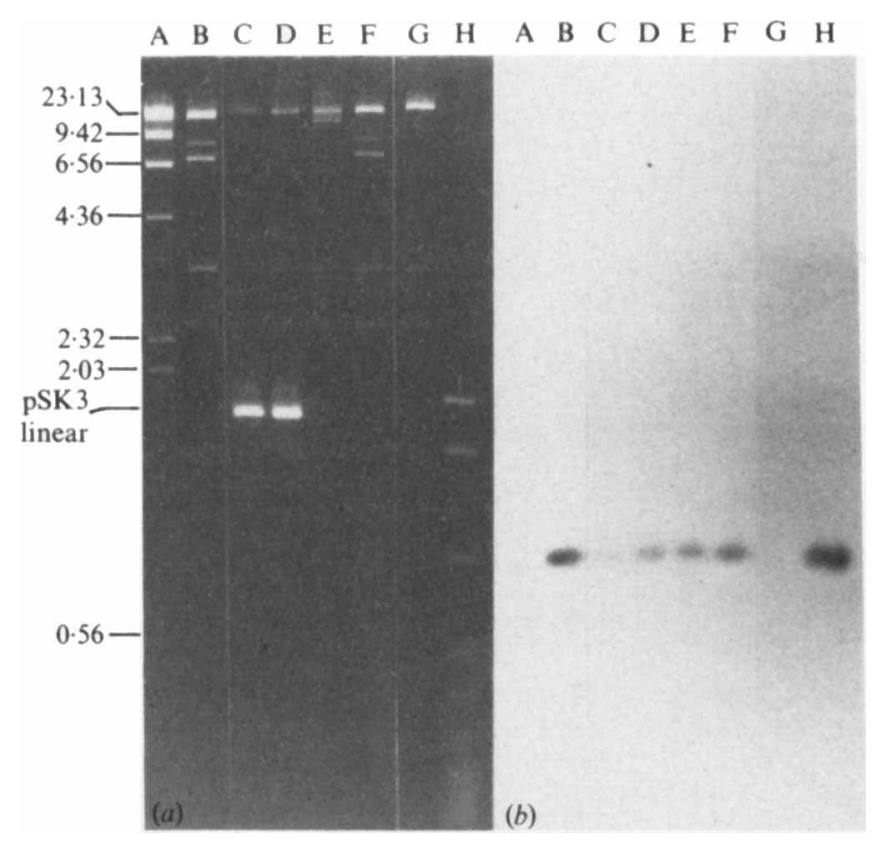

Fig. 2. (a) Agarose gel $(1 \cdot 3 \%, \mathrm{w} / \mathrm{v})$ electrophoresis of purified DNA cleaved with the restriction endonuclease $H p a I I$ : lanes: A, $\lambda$ phage DNA cleaved with HindIII as standards, with fragment sizes in kb shown at left ; B, pSK 1; C, pSK 9; D, pSK 14; E, pSK 16; F, pSK 42; G, pSK 78; H, pSK 449. It should be noted that pSK1, pSK 16, pSK42, and pSK 78 were prepared from laboratory-derived transferrants, whereas pSK 9 and pSK 14 were isolated from their clinical backgrounds which each carry two plasmids (see Table 1). In both cases, the additional plasmid was identified as pSK 3 (which possesses a single Hpall site); the linear form of pSK 3 appears in lanes C and D as an intense band of DNA. (b) Autoradiograph of the gel shown in (a) after hybridization with the $0.85 \mathrm{~kb} H p a I I$ fragment of pSK 449 . No homologous sequences were detected in lane $\mathrm{G}$ (see text).

\section{Polypeptide analysis of the qac $A$ region of $p S K 1$}

In order to identify possible translation products of the qacA determinant of pSK1, polypeptides expressed by the vector plasmid pBR322 (Fig. $3 a$, lane A) and by pSK 449 (Fig. $3 a$, lane B) were examined in $\left[{ }^{35} \mathrm{~S}\right]$ methionine-labelled maxicells prepared from strain CSR603. Polypeptides synthesized by pSK449 included proteins of apparent molecular mass $17 \mathrm{kDa}, 24$ $\mathrm{kDa}, 26 \mathrm{kDa}$ and $30 \mathrm{kDa}$, and a diffusely-banded protein of approximately $50 \mathrm{kDa}$. Of these, the $30 \mathrm{kDa}$ protein corresponded to the $\beta$-lactamase (BLA) protein encoded by pBR322. Considering that the size of the passenger DNA in pSK 449 was $3.5 \mathrm{~kb}$ it was possible that the remaining polypeptides could all be encoded by the cloned pSK 1 sequences.

The effect of selected Tn 5 insertions on the synthesis of polypeptides by pSK 449 was also examined in maxicells. The insertion mutants pSK467, pSK478 and pSK480 (Fig. 1), which retained the $\mathrm{Ac}^{r} \mathrm{~Eb}^{r} \mathrm{Qa}^{r} \mathrm{Pi}^{r} \mathrm{Dd}^{r}$ phenotype, expressed three of the proteins specified by $\mathrm{pSK} 449$, namely $17 \mathrm{kDa}, 26 \mathrm{kDa}$ and $50 \mathrm{kDa}$ (Fig. $3 a$, lanes $\mathrm{C}, \mathrm{D}$ and $\mathrm{J}$ ). In contrast, five $\mathrm{Ac}^{\mathrm{s}} \mathrm{Eb}^{\mathrm{s}} \mathrm{Qa}^{\mathrm{s}} \mathrm{Pi}^{\mathrm{s}} \mathrm{Dd}^{\mathrm{s}}$ mutants (Fig. $3 a$, lanes $\mathrm{E}-\mathrm{I}$ ), which either defined the minimum extent of qacA (pSK463 and pSK 476) or were located within these boundaries (pSK464, pSK465 and pSK 477; Fig. 1), synthesized $17 \mathrm{kDa}$ and $26 \mathrm{kDa}$ polypeptides but lacked the heavily expressed $50 \mathrm{kDa}$ protein. It should be noted that, in addition to those proteins described above, all of the transposon insertion mutants expressed several proteins, including the $29 \mathrm{kDa}$ neomycin phosphotransferase (NPT), which were encoded by Tn5 (Rothstein et al., 1980). Furthermore, longer exposure of the fluorogram shown in Fig. 3(a) revealed that the $24 \mathrm{kDa}$ polypeptide was synthesized by strains carrying each of the pSK $449:: \operatorname{Tn} 5$ derivatives but in varying amounts. In 


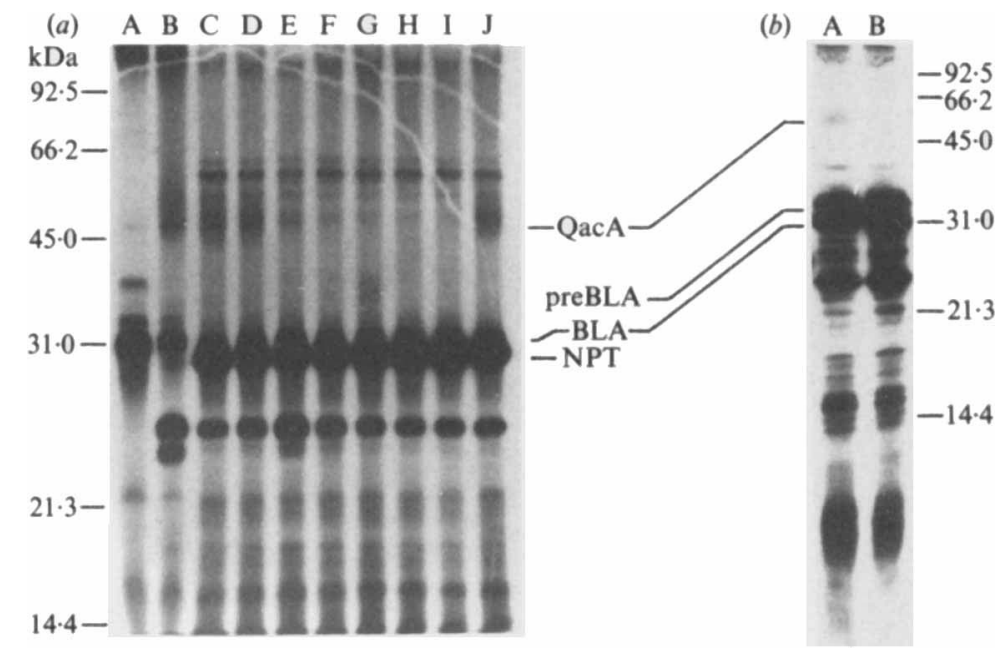

Fig. 3. Analysis of polypeptides synthesized by pSK 449 and its derivatives. (a) Fluorograph of $15 \%$ (w/v) SDS-PAGE of proteins synthesized in maxicells containing the indicated plasmid. Lanes: A, pBR322; B, pSK 449; C, pSK467; D, pSK478; E, pSK463; F, pSK464; G, pSK465; H, pSK477; I, pSK 476; J, pSK 480. (b) Autoradiograph of $15 \%(\mathrm{w} / \mathrm{v})$ SDS-PAGE of proteins synthesized in minicells containing: lane A, pSK 449; B, pSK516. The molecular masses (in kDa) of standard proteins are indicated. Positions of the vector-encoded proteins $\beta$-lactamase (BLA) and its precursor form (preBLA), and the Tn5-encoded neomycin phosphotransferase (NPT) are shown, together with the position of the $50 \mathrm{kDa}$ QacA protein (see text for details).

any event, none of the $17 \mathrm{kDa}, 24 \mathrm{kDa}$ or $26 \mathrm{kDa}$ polypeptides could be correlated with alterations in the qacA phenotype caused by the insertion of Tn5 into pSK 449.

Although strains containing plasmids pSK463, pSK464, pSK465, pSK476 and pSK477 did not encode the intensely labelled $50 \mathrm{kDa}$ protein, each showed weak expression of a similarsized polypeptide as did the control, pBR322. Conceivably, this protein could represent a vectoror host-encoded protein obscured in those lanes which displayed the heavily expressed $50 \mathrm{kDa}$ protein. This conclusion was supported by a densitometric comparison of the proteins encoded by pSK478 and pSK 463 (Fig. $3 a$, lanes D and E), which suggested that the intense, albeit diffuse, $50 \mathrm{kDa}$ protein encoded by pSK 478 was indeed a unique pSK1-encoded polypeptide (data not shown).

To positively associate the $50 \mathrm{kDa}$ protein with the qac $A$ sequences, a derivative of pSK 449 was constructed by deleting approximately $4 \cdot 1 \mathrm{~kb}$ DNA between the PvuII site at coordinate 20.35 and the PvuII site within the vector pBR322 (Fig. 1; data not shown). The resultant plasmid, pSK 516, contained only $1.7 \mathrm{~kb}$ of pSK 1 DNA (coordinates 18.65-20.35) and was deleted for the right-hand end of the qac $A$ region defined by $\mathrm{Tn} 5$ mutagenesis, the cloned portion of IS256L and approximately $2.3 \mathrm{~kb}$ of pBR322. When further compared with pSK 449, strains carrying pSK 516 were found to be $\mathrm{Ac}^{\mathrm{s}} \mathrm{Eb}^{\mathrm{s}} \mathrm{Qa}^{\mathrm{s}} \mathrm{Pi}^{\mathrm{s}} \mathrm{Dd}^{\mathrm{s}}$ and unable to express the $50 \mathrm{kDa}$ protein (Fig. $3 b$, lane B); no other polypeptide specified by pSK 449 (Fig. $3 b$, lane A) was affected by the deletion that occurred in the construction of pSK516.

According to these data, we conclude that the $50 \mathrm{kDa}$ protein encoded by pSK 449 is the product of the pSK1 qacA determinant responsible for $\mathrm{Ac}^{r} \mathrm{~Eb}^{r} \mathrm{Qa}^{r} \mathrm{Pi}^{\mathrm{r}} \mathrm{Dd}^{\mathrm{r}}$ in $S$. aureus. Consequently, we refer to this protein as QacA.

\section{Mechanism of antiseptic resistance in $S$. aureus}

The qacA-mediated mechanism by which staphylococci evade the antiseptic actions of $\mathrm{Ac}, \mathrm{Eb}$ and Qa was examined in two ways. A substrate-promoted efflux of ethidium from strain SK2267, which carries pSK1, was demonstrated in a fluorimetric assay (Fig. 4a) and also in an 

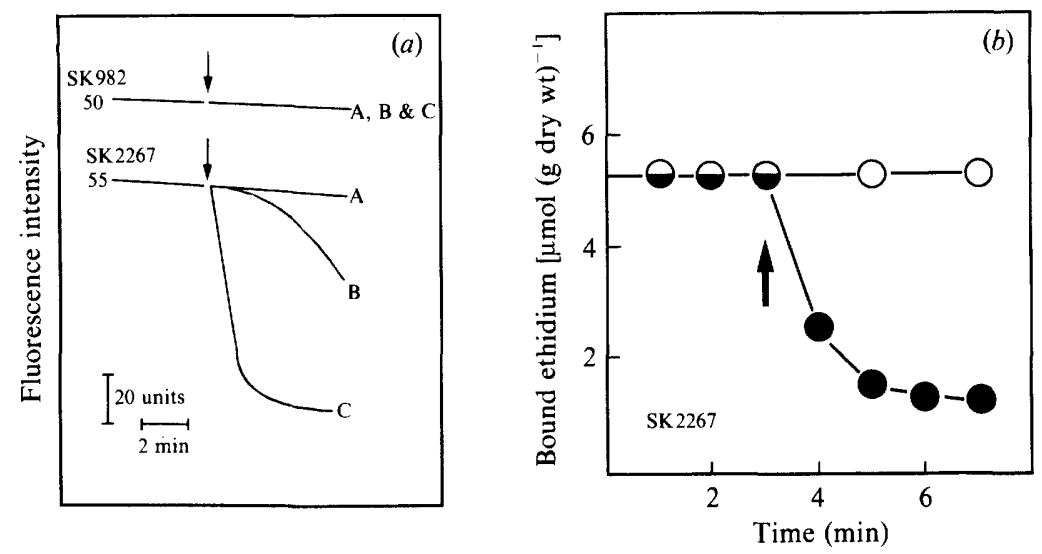

Fig. 4. (a) Fluorimetric assay of ethidium efflux. Cells of strain SK982 or SK2267 (Table 1) were loaded with ethidium bromide as described in Methods. Traces $\mathrm{A}, \mathrm{B}$ and $\mathrm{C}$ received no addition, glucose $(10 \mathrm{mM})$ or sodium formate $(10 \mathrm{mM})$, respectively, at the time indicated by the arrows. The traces are offset for clarity of presentation. The value at the beginning of each trace indicates the initial fluorescence intensity. (b) Isotopic assay of ethidium efflux. Cells of strain SK2267 were loaded with ethidium bromide as described in Methods. Cell suspension to which sodium formate (10 mM) was added at the time indicated by the arrow; $O$, no additions.

isotopic assay (Fig. $4 b$ ). The addition of formate to cells loaded with ethidium bromide supported a rate of respiration of $52 \mu \mathrm{mol} \mathrm{O}_{2} \min ^{-1}(\mathrm{~g} \text { dry wt) })^{-1}$, whereas glucose supported the lower rate of $19 \mu \mathrm{mol} \mathrm{O} \min ^{-1}(\mathrm{~g} \text { dry wt) })^{-1}$. The latter rate was established $3 \mathrm{~min}$ after the addition of glucose. A similar lag period was seen in the time course of efflux (Fig. $4 b$ ). Substrate-promoted efflux of ethidium from the background strain SK982 was not observed using either assay (Fig. $4 a$ and data not shown). Furthermore, SK982 had equivalent rates of formate- and glucose-supported respiration to those seen with SK2267, thereby demonstrating that the differences in ethidium efflux between the pSK1 (qacA)-carrying derivative and its plasmid-free host were not attributable to differences in respiration.

\section{DISCUSSION}

Almost 20 years have elapsed since staphylococcal resistance to acriflavine and ethidium bromide was associated with the presence of $\beta$-lactamase plasmids (Ericson, 1969; Johnston \& Dyke, 1969). More recently, $\mathrm{Eb}^{r} \mathrm{Qa}^{r}$ has been linked with a variety of $S$. aureus aminoglycosideresistance plasmids in Australia, the UK, the USA, Ireland and Germany (Archer \& Johnston, 1983; McDonnell et al., 1983; Naidoo et al., 1983; Lyon et al., 1984, 1987 a; Coleman et al., 1985; Goering et al., 1985; Townsend et al., 1985, 1987; Cookson \& Phillips, 1988; Skurray et al., 1988).

The data presented in this paper clearly establish the involvement of a plasmid locus, $q a c A$, in the linked expression of $\mathrm{Ac}^{r} \mathrm{~Eb}^{r} \mathrm{Qa}^{r} \mathrm{Pi}^{r} \mathrm{Dd}^{r}$ by $S$. aureus isolates from Australian hospitals. The $q a c A$ gene was found to be carried by most members of the pSK 1 family of plasmids, which are widely distributed among clinical strains (Skurray et al., 1988). The significance of this finding lies in the fact that $q a c A$ affords protection against many compounds that are part of commonly used clinical antiseptic/disinfectant formulations. As already mentioned, these agents include acriflavine (a mixture of euflavine and proflavine), cetrimide, benzalkonium chloride, propamidine isethionate and diamidinodiphenylamine dihydrochloride. Furthermore, in preliminary studies designed to explore the substrate specificity of the qacA determinant, it was found that qacA also conferred resistance to a number of other compounds including chlorhexidine diacetate, cetylpyridinium chloride, crystal violet, pentamidine isethionate, pyronin $\mathrm{Y}$, quinaldine red, rhodamine $6 \mathrm{G}$, and safranine $\mathrm{O}$ (our unpublished data). We believe 
that variations in the patterns of resistance to these compounds will be useful in distinguishing and classifying other qac determinants, such as $q a c B-E$, with respect to $q a c A$.

The mechanism by which staphylococci evade the antiseptic actions of $\mathrm{Ac}, \mathrm{Eb}$ and $\mathrm{Qa}$ has been postulated to be associated with decreased intracellular accumulation of these agents (Johnston \& Dyke, 1969; McDonnell et al., 1983). A mechanism such as this would most likely rely upon altered cellular permeability and as such may be affected by a specific protein(s) localized in the membrane matrix. In this paper, the qac $A$-determined phenotype was shown to be due to the operation of an efflux system. Sharing the same basis as those resistance mechanisms towards tetracycline, cadmium, arsenate and arsenite (Ball et al., 1980; Tynecka et al., 1981 ; Silver \& Keach, 1982; Rosen \& Borbolla, 1984), the qacA efflux system directed the rapid extrusion of ethidium from the staphylococcal cells. It is significant that tetracycline resistance in both the staphylococci and $E$. coli has been associated with a potentially membrane-bound protein (Levy \& McMurry, 1974; Mojumdar \& Khan, 1988); notably, the protein encoded by the tetracycline-resistance plasmid pT181 is also approximately $50 \mathrm{kDa}$ in size (Mojumdar \& Khan, 1988). We suggest that the $50 \mathrm{kDa}$ QacA protein specified by the qac $A$ determinant of pSK1 is a cytoplasmic-membrane-associated protein involved in an efflux system which actively reduces the intracellular accumulation of $\mathrm{Ac}, \mathrm{Eb}, \mathrm{Qa}, \mathrm{Pi}$ and $\mathrm{Dd}$. Our conclusion that QacA resides in the cytoplasmic membrane is based upon a comparison made between the characteristic diffuse appearance of QacA in SDS-PAGE and the similar migration of the $E$. coli lac carrier protein which catalyses transport of lactose through the plasma membrane of the cell (Kaback, 1983).

Since the qacA-mediated phenotype results from active transport, resistance to $\mathrm{Ac}, \mathrm{Eb}, \mathrm{Qa}, \mathrm{Pi}$ and Dd must be due to the decreased exposure of these toxicants to intracellular targets only, as levels in the cell envelope would be unaffected. That the lethal target(s) for Ac and Eb is located in the cytoplasm is not unexpected considering their established major inhibitory effects on nucleic acid synthesis (Waring, 1966); Eb is also known to inactivate ribosomes (Ballesta et al., 1976). However, the Qa compounds (benzalkonium chloride and cetyltrimethylammonium bromide) have been characterized as surface-active agents, i.e. their antiseptic properties result from disruption of cellular membranes (Petrocci, 1977). Thus, our data indicate that although Qa compounds are surface-active, major targets for their toxic activity also occur within the cell. Consistent with the intracellular action of Qa compounds, and the diamidines ( $\mathrm{Pi}, \mathrm{Dd})$, is the observed binding of these types of agents to nucleic acids (Scott, 1962; Newton, 1970): the spectrum of their intracellular targets remains to be established.

Restriction mapping and DNA hybridization experiments using the qac $A$-specific probe detailed in this study have shown sequences homologous to this determinant to be present on a variety of plasmids from clinical isolates of coagulase-negative staphylococci (J. Tennent \& $R$. Skurray, unpublished data). From these and other observations (Tennent et al., 1984, 1986, 1988; Skurray et al., 1988) it is becoming increasingly clear that members of the genus Staphylococcus within Australian hospitals share common genetic reservoirs. Such exchange, when considered along with the selective pressures imposed through the extensive application of agents such as acriflavine, cetrimide and chlorhexidine as antiseptics and disinfectants, may well account for the emergence and continuing presence of plasmid vectors which primarily encode the qacA phenotype, but that are also capable of disseminating a variety of determinants such as those for resistance to gentamicin, tobramycin, kanamycin, trimethoprim and penicillin among hospital isolates of staphylococci.

We thank Linda Messerotti for skilful technical assistance and Duncan Rouch and Matthew Gillespie for critical reading of the manuscript and valuable discussions. This work was supported in part by a Project Grant from the National Health and Medical Research Council (Australia). J.T. and B.L. were recipients of Commonwealth Postgraduate Research Awards and A.S.P. was supported by an SERC Studentship. This collaborative research was initiated during the period that R.A.S. was supported by an Australian Academies of Science and Royal Society of London Exchange Programme and a British Council Academic Links and Interchange Travel Grant at the Microbiology Unit, Department of Biochemistry, University of Oxford. 


\section{REFERENCES}

ARChER, G. L. \& Johnston, J. L. (1983). Selftransmissible plasmids in staphylococci that encode resistance to aminoglycosides. Antimicrobial Agents and Chemotherapy 24, 70-77.

Ball, P. R., Shales, S. W. \& Chopra, I. (1980). Plasmid-mediated tetracycline resistance involves increased efflux of the antibiotic. Biochemical and Biophysical Research Communications 93, 74-81.

Ballesta, J. P. G., Waring, M. J. \& Vázquez, D. (1976). Specific release of ribosomal proteins by nucleic acid-intercalating agents. Nucleic Acids Research 3, 1307-1322.

Berg, D. E., Davies, J., Allet, B. \& Rochaix, J. D. (1975). Transposition of R factor genes to bacteriophage lambda. Proceedings of the National Academy of Sciences of the United States of America 72, 36283632.

Coleman, D. C., Pomeroy, H., Estridge, J. K., Keane, C. T., Cafferkey, M. T., Hone, R. \& FosTER, T. J. (1985). Susceptibility to antimicrobial agents and analysis of plasmids in gentamicin- and methicillin-resistant Staphylococcus aureus from Dublin hospitals. Journal of Medical Microbiology 20, 157-167.

Cookson, B. D. \& Phillips, I. (1988). Epidemic methicillin-resistant Staphylococcus aureus. Journal of Antimicrobial Chemotherapy 21, Suppl. C, 57-65.

Daniels, D. L., Schroeder, J. L., Szybalski, W., SANGER, F. \& BlatTNER, F. R. (1983). A molecular map of coliphage lambda. In Lambda II, pp. 469517. Edited by R. W. Hendrix, J. W. Roberts, F. W. Stahl \& R. A. Weisberg. Cold Spring Harbor, NY: Cold Spring Harbor Laboratory.

Emslie, K. R., Townsend, D. E. \& Grubb, W. B. (1985). A resistance determinant to nucleic acidbinding compounds in methicillin-resistant Staphylococcus aureus. Journal of Medical Microbiology 20, 139-145.

Emslie, K. R., Townsend, D. E. \& Grubb, W. B. (1986). Isolation and characterization of a family of small plasmids encoding resistance to nucleic acidbinding compounds in Staphylococcus aureus. Journal of Medical Microbiology 22, 9-15.

ErICson, C. (1969). Resistance to acriflavine and cadmium, and changed phage reactions - markers of a new staphylococcal penicillinase plasmid. Acta pathologica et microbiologica scandinavica 76, 333.

Evans, J. \& DYKe, K. G. H. (1988). Characterization of the conjugation system associated with the Staphylococcus aureus plasmid pJE1. Journal of General Microbiology 134, 1-8.

FOSTER, T. J. (1983). Plasmid-determined resistance to antimicrobial drugs and toxic metal ions in bacteria. Microbiological Reviews 47, 361-409.

Gillespie, M. T. \& SkurRay, R. A. (1986). Plasmids in multiresistant Staphylococcus aureus. Microbiological Sciences 3, 53-58.

Gillespie, M. T., MaY, J. W. \& Skurray, R. A. (1986). Plasmid-encoded resistance to acriflavine and quaternary ammonium compounds in methicillin-resistant Staphylococcus aureus. FEMS Microbiology Letters 34, 47-51.

Goering, R. V., Teeman, B. A. \& Ruff, E. A. (1985). Comparative physical and genetic maps of conjugal plasmids mediating aminoglycoside resistance in
Staphylococcus aureus strains in the United States. Zentralblatt für Bakteriologie und Hygiene Suppl. 14, 675-678.

Johnston, L. H. \& DYKe, K. G. H. (1969). Ethidium bromide resistance, a new marker on the staphylococcal penicillinase plasmid. Journal of Bacteriology 100, 1413-1414.

JoNES, I. G. \& Midgley, M. (1985). Expression of a plasmid borne ethidium resistance determinant from Staphylococcus in Escherichia coli: evidence for an efflux system. FEMS Microbiology Letters 28, 355358.

KABACK, H. R. (1983). The lac carrier protein in Escherichia coli. Journal of Membrane Biology 76, 95112.

LeVy, S. B. \& MCMurRY, L. (1974). Detection of an inducible membrane protein associated with $\mathbf{R}$ factor mediated tetracycline resistance. Biochemical and Biophysical Research Communications 56, 1060 1068 .

Lyon, B. R. \& SkURRaY, R. A. (1987). Antimicrobial resistance of Staphylococcus aureus: genetic basis. Microbiological Reviews 51, 88-134.

Lyon, B. R., May, J. W. \& Skurray, R. A. (1983). Analysis of plasmids in nosocomial strains of multiple-antibiotic-resistant Staphylococcus aureus. Antimicrobial Agents and Chemotherapy 23, 817826.

Lyon, B. R., MAY, J. W. \& Skurray, R. A. (1984). Tn 4001: a gentamicin and kanamycin resistance transposon in Staphylococcus aureus. Molecular and General Genetics 193, 554-556.

Lyon, B. R., Gillespie, M. T., Byrne, M. E., May, J. W. \& SkURray, R. A. (1987a). Plasmid-mediated resistance to gentamicin in Staphylococcus aureus: the involvement of a transposon. Journal of Medical Microbiology 23, 101-110.

Lyon, B. R., Gillespie, M. T. \& Skurray, R. A. $(1987 b)$. Detection and characterization of IS256, an insertion sequence in Staphylococcus aureus. Journal of General Microbiology 133, 3031-3038.

Maniatis, T., Fritsch, E. F. \& SaMbrooK, J. (1982). Molecular Cloning: a Laboratory Manual. Cold Spring Harbor, NY: Cold Spring Harbor Laboratory.

McDonnell, R. W., Sweeney, H. M. \& Cohen, S. (1983). Conjugational transfer of gentamicin resistance plasmids intra- and interspecifically in Staphylococcus aureus and Staphylococcus epidermidis. Antimicrobial Agents and Chemotherapy 23, 151-160.

MIDGLEY, M. (1986). The phosphonium ion efflux system of Escherichia coli: relationship to the ethidium efflux system and energetic studies. Journal of General Microbiology 132, 3187-3193.

MOJUmDaR, M. \& KhAN, S. A. (1988). Characterization of the tetracycline resistance gene of plasmid pT181 in Staphylococcus aureus. Journal of Bacteriology (in the Press).

Naid0O, J., Noble, W. C., Weissmann, A. \& Dyke, K. G. H. (1983). Gentamicin-resistant staphylococci: genetics of an outbreak in a dermatology department. Journal of Hygiene 91, 7-16.

Newton, B. A. (1970). Chemotherapeutic compounds affecting DNA structure and function. Advances in Pharmacology and Chemotherapy 8, 149-184. 
Orndorff, P. E., Spears, P. A., Schaver, D. \& FALKow, S. (1985). Two modes of control of pilA, the gene encoding type 1 pilin in Escherichia coli. Journal of Bacteriology 164, 321-330.

PetrocCI, A. N. (1977). Quaternary ammonium compounds. In Disinfection, Sterilization and Preservation, 2 nd edn, pp. 325-347. Edited by S. S. Block. Philadelphia: Lea \& Febiger.

RAY, A. \& SkURRAY, R. (1983). Cloning and polypeptide analysis of the leading region in F plasmid DNA transfer. Plasmid 9, 262-272.

Rosen, B. P. \& Borbolla, M. G. (1984). A plasmidencoded arsenite pump produces arsenite resistance in Escherichia coli. Biochemical and Biophysical Research Communications 124, 760-765.

Rothstein, S. J., Jorgensen, R. A., Postle, K. \& REZNIKOFF, W. S. (1980). The inverted repeats of Tn5 are functionally different. Cell 19, 795-805.

SANCAR, A., HACK, A. M. \& RupP, W. D. (1979). Simple method for the identification of plasmidcoded proteins. Journal of Bacteriology 137, 692-693.

ScoTT, J. E. (1962). The precipitation of polyanions by long-chain aliphatic ammonium salts. 6 . The affinity of substituted ammonium cations for the anionic groups of some biological polymers. Biochemical Journal 84, 270-275.

SILVER, S. \& KEACH, D. (1982). Energy-dependent arsenate efflux : the mechanism of plasmid mediated resistance. Proceedings of the National Academy of Sciences of the United States of America 79, 61146118.

Skurray, R. A., Rouch, D. A., Lyon, B. R., Gillespie, M. T., Tennent, J. M., Byrne, M. E., Messerotti, L. J. \& MAY, J. W. (1988). Multiresistant Staphylococcus aureus: genetics and evolution of epidemic Australian strains. Journal of Antimicrobial Chemotherapy 21, suppl. C, 19-38.

Smith, G. E. \& Summers, M. D. (1980). The bidirectional transfer of DNA and RNA to nitrocellulose or diazobenzyloxymethyl-paper. Analytical Biochemistry 109, 123-129.

Tennent, J. M., May, J. W. \& Skurray, R. A. (1984). Multiple antibiotic resistance in Staphylococcus aureus and Staphylococcus epidermidis: plasmids in strains associated with nosocomial infection. Pathology 16, 250-255.
Tennent, J. M., Lyon, B. R., Gillespie, M. T., May, J. W. \& Skurray, R. A. (1985). Cloning and expression of Staphylococcus aureus plasmid-mediated quaternary ammonium resistance in Escherichia coli. Antimicrobial Agents and Chemotherapy 27, 7983.

Tennent, J. M., May J. W. \& Skurray, R. A. (1986). Characterisation of chloramphenicol resistance plasmids of Staphylococcus aureus and Staphylococcus epidermidis by restriction enzyme mapping techniques. Journal of Medical Microbiology 22, 79-84.

Tennent, J. M., Young, H.-K., Lyon, B. R., Amyes, S. G. B. \& Skurray, R. A. (1988). Trimethoprim resistance determinants encoding a dihydrofolate reductase in clinical isolates of Staphylococcus aureus and coagulase-negative staphylococci. Journal of Medical Microbiology 26, 67-73.

ThOMPSON, R. \& ACHTMAN, M. (1978). The control of the $F$ sex factor DNA transfer cistrons: restriction mapping and DNA cloning. Molecular and General Genetics 165, 295-304.

Townsend, D. E., Ashdown, N., Момон, M. \& GRUBB, W. B. (1985). Distribution of plasmid-borne resistance to nucleic acid binding compounds in methicillin-resistant Staphylococcus aureus. Journal of Antimicrobial Chemotherapy 15, 417-434

Townsend, D. E., Ashdown, N., Bolton, S., BradLEY, J., DuCKWorth, G., Moorhouse, E. C. \& GruBB, W. B. (1987). The international spread of methicillin-resistant Staphylococcus aureus. Journal of Hospital Infection 9, 60-71.

TyNeCKA, Z., Gos, Z. \& ZAJAC, J. (1981). Energydependent efflux of cadmium coded by a plasmid resistance determinant in Staphylococcus aureus. Journal of Bacteriology 147, 313-319.

WARING, M. J. (1966). Cross-linking and intercalation in nucleic acids. In Biochemical Studies of Antimicrobial Drugs (Society for General Microbiology Symposium no. 16), pp. 235-265. Edited by B. A. Newton $\&$ P. E. Reynolds. Cambridge: Cambridge University Press.

WeAver, C. A., Redborg, A. H. \& Konisky, J. (1981). Plasmid determined immunity of Escherichia coli $\mathrm{K} 12$ to colicin Ia is mediated by a plasmid-encoded membrane protein. Journal of Bacteriology 148, 817 828. 